\title{
Theocratic rule, native agency and transformation: post-crusade sacred landscapes in the eastern Baltic
}

Article

Accepted Version

Pluskowski, A., Valk, H. and Szczepański, S. (2018)

Theocratic rule, native agency and transformation: postcrusade sacred landscapes in the eastern Baltic. Landscapes, 19 (1). pp. 4-24. ISSN 1466-2035 doi:

https://doi.org/10.1080/14662035.2018.1561009 Available at https://centaur.reading.ac.uk/81384/

It is advisable to refer to the publisher's version if you intend to cite from the work. See Guidance on citing.

To link to this article DOI: http://dx.doi.org/10.1080/14662035.2018.1561009

Publisher: Maney

All outputs in CentAUR are protected by Intellectual Property Rights law, including copyright law. Copyright and IPR is retained by the creators or other copyright holders. Terms and conditions for use of this material are defined in the End User Agreement.

www.reading.ac.uk/centaur 
Central Archive at the University of Reading

Reading's research outputs online 


\title{
Theocratic Rule, Native Agency and Transformation: post-Crusade Sacred Landscapes in the Eastern Baltic
}

\author{
Aleksander Pluskowski ${ }^{1 .}$ *, Heiki Valk ${ }^{2}$, Seweryn Szczepański ${ }^{3 .}$ \\ ${ }^{1 .}$ Department of Archaeology, University of Reading, UK, ${ }^{2}$ Institute of History and Archaeology, \\ University of Tartu, Estonia, ${ }^{3 \cdot}$ Wojciech Kętrzyński Research Centre in Olsztyn, Poland.
}

\begin{abstract}
The crusades against eastern Baltic societies from the end of the twelfth century saw the reorganisation of the conquered territories into new Christian polities - Livonia and Prussia largely ruled by a militarised theocracy consisting of the Teutonic Order, bishops and cathedral chapters. This was accompanied by the reconfiguration of land ownership and intensification in resource exploitation aimed at sustaining the new regime, alongside the growing urban and rural populations. An ecclesiastical administration was also imposed on the conquered territories, alongside the construction of churches and monasteries, confronting native religions which attached sacred importance to natural places and cemeteries. This paper compares the transformation of sacred landscapes in Livonia and Prussia and provides an interpretation of variability in relation to theocratic authority, native and migrant populations. Encompassing the role of settlements, cemeteries and the tempo of change, the paper is situated within a new archaeological framework contextualising religious transformation in the Middle Ages. It also provides the first detailed, comparative perspective for the two regions. The landscape was not uniformly transformed and its variability, particularly the post-crusade endurance and even proliferation of native sacred sites, reflects the limits of theocratic authority and the pragmatic necessities of ruling a conquered population. That strong contrasts exist in the nature and process of Christianisation in even superficially similar areas like Livonia and Prussia should serve as a warning to resist generalising across limited data sets.
\end{abstract}

Keywords: Crusades, Baltic, paganism, Christianity, sacred landscapes

Graphic abstract: The offering tree of Öövesti farmstead in Räägu village, Halliste parish, Viljandimaa, Estonia (Photo: Heiki Valk, 2004).

\section{Introduction}

The crusades waged against native pagan ${ }^{1}$ societies in the eastern Baltic region from the late-twelfth century AD resulted in their disenfranchisement and the reorganisation of the conquered territories into two Christian polities - Livonia and Prussia - which, except for northern Estonia subordinated

* Contact: a.g.pluskowski@reading.ac.uk 
to the Danish crown until 1346, were governed by a militarised Christian theocracy: the Teutonic Order, bishops and their cathedral chapters (Figure 1). Several Livonian and Prussian towns also came to play important political roles. The conquests had initially synchronised various political agendas of neighbouring Catholic powers, but they were ultimately subordinated to crusading authorities supported by the papacy which sought to protect Christian converts and disseminate Catholicism amongst the Baltic and Finno-Ugric societies of north-eastern Europe (Christiansen 1997; Urban 2003; Fonnesberg-Schmid 2007). In order to sustain a lasting Christian presence, the conquered territories were secured with castles, of which the majority were built by the Order, and a hierarchy was established dominated by fortified monasteries (referred to in the scholarly literature as Konventsburgen or conventual castles) headed by commanders and governing a patchwork of administrative districts (Ämter) (Biskup et al. eds. 2009; Czaja and Radzimiński 2013). The process of reorganising the landscape continued into the fourteenth century, and in some regions into the fifteenth, with the designation of new districts. Alongside a sustained military presence, the theocracy encouraged migrants from neighbouring Christian regions to settle in towns in Livonia, and in both urban and rural areas in Prussia. The detailed reallocation of land and natural resources was a defining policy of the new regime that permeated every aspect of life in the conquered territories, mapping out power relations with both the native population and incoming migrants. Place fig 1 near here, full page width

Native communities in the eastern Baltic attached spiritual significance to a variety of natural places and to their cemeteries. Sacred landscapes are thus not an ephemeral or peripheral research topic but rather lie at the heart of understanding the resilience of native populations in the face of conquest, colonisation, the reorganisation of territory and the imposition of Christianity. The process of restructuring was intended to fulfil the objective of the Crusades promoted by the papacy and the Teutonic Order's apologists - the suppression of pre-Christian cult praxis and the conversion of the subjugated population to Catholicism - but this objective was not met.

There is a substantial body of scholarship on sacred natural sites and sacred landscapes in the eastern Baltic stretching back into the late nineteenth century and written in local languages, but in the last decade there has been a noticeable increase in studies in English, including a seminal interregional synthesis largely based on place names (Vaitkevičius 2004) alongside regional studies which have included both sacred natural sites and built structures (e.g. for Estonia: Jonuks 2007, 2012a, b,; Valk 2009, 2018; for Latvia: Urtāns 2008a; for Lithuania: Vaitkevičius 2009, 2011, 2018; for Prussia: Wenta 2011; (ed) 2013; Szczepański 2018; for local language works see the bibliographies in these cited studies). The CCC project (Culture, Clash or Compromise, 1998-2001) contributed to raising international awareness of sacred landscapes in the Baltic region, whilst seven interdisciplinary meetings in 2007-2013 brought together archaeological, folkloristic and historical research in the eastern Baltic region, from which some outputs have been published (Jonuks 2009; Vaitkevičius and Vaitkevičienė 2011; Urtāns 2011). Eastern Baltic landscapes have also begun to feature within broader discussions of sacred geography (e.g. Kõivupuu 2009), with the recognition of the biocultural values of sacred natural sites connected to sustaining local identities and conservation (Frascaroli and Verschuuren 2016; for the case of Estonia see Heinapuu 2016). The term 'biocultural' has been adopted in this paper in recognition of the cultural roles assigned to natural environmental features. The general themes that have emerged from this body of scholarship are the similarities in site types and how they were used across the Baltic region, the relationship between 
sites and territorial boundaries, the use of multiple sites by the same community, and trends in the post-medieval creation of new sites. Although precise dating of the period of use of any given site remains a significant challenge, a critical approach is nonetheless possible when using a diverse range of sources and acknowledging their variable chronological resolution.

This paper builds on the existing body of scholarship with a comparison of sacred landscapes in Livonia and Prussia, regions which both fell under the rule of an aggregate of theocratic authorities, but which experienced very different demographic changes associated with spatially and temporally uneven waves of migration from neighbouring Catholic states. Situated within the framework of a new archaeological agenda for contextualising religious transformation (Thomas et al. 2017), it draws on data collected during the Ecology of Crusading project and related research, assessing whether the impact of the crusades and regime change was comparable in both regions (Pluskowski (ed) 2018). This comparative approach highlights the value of considering the variable tempo of religious transformation in a part of Europe that nominally came under a common form of militarised Christian governance, but which resulted in different regional trajectories.

\section{Transforming the biocultural landscapes of the eastern Baltic}

At the heart of territorial reorganisation in the eastern Baltic was the reallocation of land and natural resources (Pluskowski (ed) 2018), resulting in varying proportions of cultivated land, pasture, woods and wetlands within each district. Although the area under cultivation generally increased after the crusades, reinforcing earlier trends in environmental exploitation in the eleventh to thirteenth centuries, this did not result in widespread deforestation and parts of Prussia and Livonia remained heavily wooded (Brown 2018a, b). The export of grain and timber was an economic staple of Prussia by the late fourteenth century and of Livonia in the fifteenth, whilst by-products of woodland exploitation included charcoal, ash, pitch, tar, honey, wax and fur, with amber as a luxury export acquired from the coastal zone (Jahnke 2015). Quarried limestone and clay in Livonia, and particularly the latter in Prussia, became essential for constructing the durable structures that replaced the timber buildings constructed in the thirteenth century. The new regime also actively modified local hydrology, creating canals for mills, diverting streams, connecting lakes, and building moats and ponds (Steege 1993; Karczewski 2008; Bonow et al. 2016) (Figure 2). Did these modified elements of the physical landscape intersect with native sacred landscapes? In the twentieth century, particularly during the Soviet Period, the intensive industrialisation of the eastern Baltic countries saw the destruction of places defined in cultural memory as sacred sites (Kõivupuu 2009, 226). Given the confrontational ideology of the crusading movement, did this also occur in the Middle Ages?

Place fig 2 near here, quarter page?

\section{Reorganising sacred landscapes}

The introduction (or in some areas potentially re-introduction) of Christianity was facilitated by the creation of an ecclesiastical hierarchy, which divided the conquered territories into dioceses. This process was effectively completed during the crusading period. Dioceses in Livonia and Prussia were 
established by the 1250s, with Riga elevated to the status of archdiocese in 1255 with nominal jurisdiction over both territories, although Samogitia, one of the principal targets of the Teutonic Order's subsequent campaigns, was not organised into a diocese until 1417. The designation of parishes continued in the fourteenth and fifteenth centuries. This was accompanied by the construction of cathedrals, churches, chapels (including oratories) and a smaller number of monasteries (Biskup and Radzimiński eds. 2015). Public rituals of consecration and legal regulations designated these churches as sacred spaces, as places of asylum, and their defilement became punishable in various ways, including by death. They also functioned as places of public assembly and focal points of communal life (Simiński 2013, 298-299, 305), whilst churches and roadside chapels became important landmarks.

Place fig 3 near here, quarter page?

The theocratic character of the new regime meant that its fortified residences functioned as important religious centres, each with one or more chapels and several incorporating Christ, Mary, archangels, saints and references to sanctity in their names (Figure 3). The presence of relics also attracted pilgrims, such as the relic of the Holy Blood in Riga (Gąssowska 2006), the True Cross at Elbing, the relics of St Barbara at Althausen Höhe and St Catherine at Brandenburg (for a comprehensive list see Rozynkowski 2006). Participants in the Order's campaigns (Reisen) into Lithuania would visit shrines within the vicinity of Königsberg, particularly the churches of St Catherine in Arnau and Juditten, and the chapels of St George and St Anthony in the suburbs (Paravicini 1989, 305). The new religion was also visibly defined in the landscape with representations of the cross, ranging from marks cut into trees to free-standing stone and timber monuments (Figure 4), which simultaneously functioned as boundary markers, Christian monuments and reminders of theocratic authority (Pluskowski et al. 2018). Taken together these structures mapped a Christian sacred landscape onto the conquered territories (Rozynkowski 2006, 229-240), but their distribution and chronology varied within both Livonia and Prussia. The construction of durable churches outside major towns began from the mid-thirteenth century in Estonia (Markus 1999, 153-221), but in parts of Eastern Prussia only from the mid-fourteenth century or later. Although missionary activities during the crusading period became pragmatic (Murray 2016), the limited native engagement with Christianity appears to have remained a consistent problem as indicated by clerical complaints in the fifteenth and sixteenth centuries (e.g. Valk 2003).

The officials of the theocratic regime were very aware of native sacred sites, as is evident from their meticulous recording of toponyms that recognise an explicitly sacred function. These names were usually explicit, whether in German (e.g. heiligenwalde meaning sacred wood), or by adopting native names with a sacral function (e.g. a Livonian example of a sacred wood called Elkewalke, where elks referred to a pagan 'idol' and valks to a slow-running brook). For modern analysts this presents an interesting paradox: on the one hand, paganism represented 'the other' for Christians in Livonia and Prussia, but at the same time its manifestation in the landscape was considered acceptable enough to be preserved, and even to serve a valid function within territorial organisation. The recording of native sacred sites by the Teutonic Order and episcopates is striking, serving a bureaucratic rather than ethnographic purpose. However, there is a noticeable contrast between Livonia and Prussia in the preservation of toponyms. In the latter, the gradual extinction of indigenous Prussian culture ensured that such mnemonic landscape connections did not endure to the same extent as they did in Livonia or Lithuania (cf. Vaitkevičius 2004). 


\section{Place figs 4 and 5 near here, side by side if possible}

The typology of native cult sites in the eastern Baltic is well established, and virtually all feature in some respect in medieval land charters. They include wetlands (lakes, springs, rivers, bogs), trees (from individuals to discrete woodlands), stones (often substantial glacial erratics, but also unusually marked or altered boulders, Figure 5), striking geological features (including hills and caves) fields or meadows and cemeteries (see Vaitkevičius 2004; Urtāns 2008a, 14-21; Kawiński and Szczepański 2016). It is important to qualify the inclusion of cemeteries as a category of sacred site. The influence of the post-processual theoretical school on medieval archaeology prompted a critical reconsideration of the role of cemeteries, especially during periods of religious change (Williams 2005). Religion has been acknowledged as one of several social identities being expressed during the process of burial and memorialisation. In the eastern Baltic, the acknowledgement of cemeteries as sites of religious praxis has generally been accepted by scholars over the last century. But it is also clear that political authority and the reinforcement of social relations were an integral function of funerary rites, underpinned by a cosmology that connected earthly and otherworldly identities (Bertašius 2006; see also Williams 2004). A striking example of this connection can be seen in the deposit of horses within cemeteries in pre-crusade Prussia, Lithuania and the territories of the Daugava Livs, Semigallians and Curonians, and in the use of equestrian equipment as grave goods more widely in the eastern Baltic (Brūzis and Spirgis 2011; Shiroukhov 2012; Lang 2017). There is evidence that some cemeteries contained discrete areas used for cult activities (Urtāns 2008a, 50), with unusual examples, including the use of linear horse deposits at Marvele to segregate spaces (Bertašius 2005; 2012).

For the conquering Christian regime and its affiliated migrants, places of burial and the rites conducted within them defined a visibly important religious identity, contributing to the reinforcement of the pagan other in Livonia and Prussia. Several articles within the Treaty of Christburg between the Teutonic Order and the West Prussian nobility in 1249 which officially ended the First Prussian Uprising, dealt with burial rites and the presence of ritual specialists; socalled tullisones vel ligaschones (PUB 1/1, 218; Szczepański 2017, 86-89). Following the crusades, attitudes to burial are most visible in long-term trends in funerary rites associated with urban and rural communities (Valk 2001; 2004a; Muižnieks 2015). In 1425, following the decisions of the Sambian diocesan synod, Bishop Michael Junge forbade Prussians 'to gather according to the pagan customs by burial mounds and graves called geten or cappyn in their language' $(G Q K, 128)$. This suggests that native communities had continued to practice cyclical ceremonies linked to the memory of their ancestors. A few years later, in 1428, the Provincial Synod of Riga condemned the practice of burial in unconsecrated sites in the wilderness (in campis silvestribus) 'together with wild animals - in places where their ancestors and relatives were buried in the time of heathendom' (LUB VII, 690). But the only discernible change appears to have been a closer integration of village cemeteries with Christianity, represented by the consecration (or at least blessing) of sites, and the addition within their bounds of visible Christian symbols such as chapels or large crosses (Valk 2018). Moreover, the same Synod also condemned the substantial number of illicit chapels with statues of St Anthony and other saints, decreeing that any built without ecclesiastical permission must be demolished within a year at the expense of the builder (LUB VII, 690, 29). In Prussia, early sixteenth century sources documented native beliefs relating to the afterlife, emphasising the spiritual 
importance of proper burial rites (Możdżeń 2013). When comparing sacred landscapes in Livonia and Prussia, cemeteries provide the best dated examples of native responses to the theocratic regime.

\section{Livonia}

The two principle chronicles for the crusades which resulted in the creation of Livonia, Henry's Chronicle of Livonia and the anonymous Livonian Rhymed Chronicle, treat the landscape as an active backdrop to the spiritual war (Nielsen 2013). The landscape, particularly its dense woodlands, is depicted as a pagan 'other'. In stark contrast, the castles and towns built by the crusaders were beacons of light embedded within this dark wilderness (Lazda-Cazers 2009; Nielsen 2011).

Importantly, the crusades were accompanied by the construction of churches, in some cases built in relation to native sacred sites. In southern Estonia, most medieval churches were founded on preChristian cemeteries (Valk 2017). A cathedral was built on top of a likely Liv cult site dating to the twelfth century in the southern part of Riga as the town was expanded towards the river (Caune 1992); the principal base for crusading aimed at securing what became quickly branded as Terra Mariana - the Land of Mary. The building of castles on two cult hills in Semigallia, close to the hillforts at Tērvete (Heiligenberg) and Dobe, may also have been intended to symbolise the conquest of the pagan landscape (Urtāns 2008a, 65). However, in contrast to the struggle with paganism pitched in the chronicles, theocratic authorities were far more pragmatic in securing the loyalty of their native vassals, and their investment in Christian sites also varied.

In Curonia (German Courland), there is early evidence for distinguishing sacred sites from other forms of property. A document issued jointly by the Bishop of Courland and the representative of the Grand Master of the Teutonic Order on 18 October 1252, states that priests and the newly founded parishes within this diocese would own wood-felling sites, except for those woods which had previously been referred to as holy (heilich) $(L U B, 1 / 240,304)$. This concern for the interests of native Curonian vassals was reiterated the following year in a record of the division of lordship over Curonia between the episcopate and the Order, specifying that a sacred lake in the territory of Dovzare (Lake Pape) would not be divided among the parties ( $L U B, 1 / 248,325)$. This would continue into the sixteenth century and the abundant record of sacred natural sites preserved in Curonian toponyms reflects a consistent, long-term relationship between the theocracy and its native vassals (Vaitkevičius 2004). This is reinforced by the French knight Guillebert de Lannoy's description in the early fifteenth century of funerary cremation rites conduced in a grove (Spekke 1995, 94-97), and Reinhold Lubenau's eyewitness account from 1585 of a hunt in the Elka grove (described as a sacred woods) on Christmas Day, next to the village of Koninciems (Turlava parish). During this hunt, no trees were damaged and no animals were killed other than the chosen quarry of deer and hares, which were cooked and placed on a table with many candles representing the souls of the community and its ancestors - the centrepiece of a revelrous feast (Švābe 1938, 182-183; Laime 2009). Curonian examples are often cited in generalist literature, but the datasets for Livonian sacred landscapes are unevenly represented. In Latvia, the only comprehensive survey of sacred sites (including those connected with Christianity) has been conducted in Semigallia where 239 sites have been identified, although problems with dating these has limited conclusions that can be made about the impact of the crusades (Urtāns 2008a). Syntheses also exist for Selonia (Urtāns 2008b), whilst the general scarcity of documented sacred sites in southern and eastern Vidzeme (Latvia) is striking. 
However, the most comprehensive surveys have been conducted for Estonia (Valk 2004b, 2009), particularly in the south-west (Valk 2009; 2018), providing the opportunity to compare the sacred landscapes on the territories of the Teutonic Order and the neighbouring episcopate of Dorpat (Est. Tartu). Here, the traditional problems of dating sacred sites can be mitigated to some extent by synchronising their relationship with the settlement pattern.

Place figs 6 and 7 near here, same page, vertically

The most substantial analysis of the dataset has been presented for northern Viljandimaa, within the former Teutonic Order's commandery of Fellin (Figures 6 and 7). Here in the most densely populated region with settlements of prehistoric origin, most sacred natural sites were located at villages which were inhabited in the late seventeenth century, and which had their own cemetery. Villages without cemeteries also lacked sacred natural sites and are probably later than those with local burial grounds. Some villages located close to parish centres were associated with a sacred natural site but used the churchyard for burial. In areas with dense populations, the presence of a village cemetery seems to therefore be a requisite for sacred natural sites, suggesting the latter are not post-medieval but date back to at least the medieval period, or in the case of villages with prehistoric origins, earlier. Continuity in the use of sacred sites is therefore plausibly linked to older population centres, whilst peripheral regions which saw settlement expansion in the post-crusade period resulted in the designation of new sacred natural sites. In the southern part of Viljandimaa where settlement was more dispersed, continuity in the use of sacred sites may also correlate with older settlement units. A specific feature of this southern region is the large number of offering sites, consisting of a sacred tree or stone, or an enclosed sacred area, connected with individual farmsteads. These numerous sites were actively used until the mid-nineteenth century (Loorits 1935), and whilst many may be of post-medieval origin, the tradition is most likely an ancient one. Of the 410 recorded village cemeteries and 270 sacred natural sites in the study area, only six cemeteries were directly associated with sacred natural sites. The distribution pattern of sacred natural sites, as known from folkloric and toponymic evidence, does not show any differences between the Order's and bishop's territories (Figure 6): the blank spaces on the map are largely areas unsuitable for cultivation and associated settlement.

Christian sites, on the other hand, do not generally map onto this network (Figure 7). The Order's territory in Viljandimaa has a total of 45 sites linked to church or chapel toponyms, including a few major, central sanctuaries. In addition, 27 stone crosses (in 25 locations) and at least 32 stones with cross marks (in 28 locations) have been recorded, although very few have been preserved. In five parish centres - Tarvastu, Viljandi, Halliste, Helme and Põltsamaa - there are references to sacred natural sites, which in the case of Tarvastu and Viljandi also served as places for popular ritual assemblies and animal sacrifices and were located close to the church and/or parsonage. In the case of rural chapels, known on the basis of toponyms or oral lore, six examples are associated with sacred natural sites. In five of these places, native cemeteries were also located nearby, whilst Vanamõisa chapel alone was located close to an offering stone and two juniper trees where offerings were deposited. Overall, less than eight percent of all chapels, represented in folkloric data, relate to village cemeteries in the case study area. Sacred natural sites also appear near the Order's castles, as in the case of the healing springs at Helme and Karksi, the sacred grove and spring at Põltsamaa, a less precise mnemonic record of a sacred site on the lake shore at the foot of the castle at Viljandi, and tentative archaeological evidence of an offering site on a nearby hill 
(Rammo and Veldi 2005, 108; Valk 2018). There was also no attempt to rebrand sacred natural sites with Christian saints in this region, for saints' names occur solely in connection with chapels, and this is also characteristic for the territory of Estonia as a whole.

These trends are indicative of tolerance or indifference from regional ecclesiastical authorities, and native sacred sites continued to be used and designated after the establishment of a diocesan and parochial network. At the same time, they can be interpreted as representing parallel and occasionally intersecting belief systems, although the significantly higher number of sacred natural sites in the folkloric data compared to chapels suggests the latter had more expansive hinterlands. However, from the later medieval period there was no visible opposition between Christianity and paganism - elements of both worldviews existed alongside each other under the common umbrella of medieval vernacular religion and practices. Chapels appear to have been used in relation to specific holidays associated with their dedications, whilst sacred natural sites were used by local communities more regularly. Less than eight percent of all chapels were also built in or near village cemeteries. The largest number of chapels are attested in the territory of the Dorpat episcopate (Valk 2001, 24, fig. 11), with a significantly smaller number in the neighbouring territory governed by the Order, where fewer cemeteries are associated with chapel toponyms. In contrast to the episcopates, the Teutonic Order did not encourage the construction of rural chapels.

In summary, the sacred landscape in southern Estonia can be explained in relation to trends in settlement that largely reflect the growth of the native population. The landscape included a range of sites both Christian and non-Christian in character forming separate networks with little evidence of spatial overlapping, within the Order's territory as well as the bishoprics of Dorpat and Ösel-Wiek (Valk 2004b). A similar situation can also be observed in other areas of Estonia. The Christianisation of the rural landscape therefore remained limited to the establishment of parish churches and road markers, some of which were spatially related to sacred natural sites where the two belief systems met in the landscape. The only likely major change in the native sacred landscape was that the hinterlands of major pre-crusade cult centres were reduced to serving only local communities. This situation appears comparable in Curonia, where relationships between native settlements and sacred sites are specified in enfeoffment documents and in Semigallia, where the construction of parish churches and chapels was also limited in relation to the native settlement pattern (Urtāns 2008a, 16).

\section{Prussia}

The principal narrative of the Prussian Crusade, Peter of Dusburg's Chronicle of Prussia, casts the landscape in similar terms to the Livonian chronicles - the backdrop for an apocalyptic struggle between Christianity and paganism. Again, the construction of churches was essential to this struggle, alongside the deposition of relics in the chapels of the Teutonic Order's castra. An uncompromising attitude is also evident in the Treaty of Christburg (1249) (PUB 1/1, 218). The treaty required the Prussians to build new churches and rebuild those destroyed in Pomesania (Szczepański 2013), but largely focused on rites conducted at cemeteries, including the deposition of valuables, horses, offerings and the role of ritual specialists. In Prussia, the struggle against paganism continued to be emphasised in the fourteenth century through the iconographic programmes found in the Order's castles (Kutzner 1995), alongside the Lithuanian Reisen. In contrast to Livonia, the 
regular influx of Catholic migrants into rural Prussia contributed to a substantial grass roots proliferation of Christianity across the region (Biskup 2013; Biskup and Radzimiński 2015). The datasets for Prussian sacred landscapes are comparatively more limited than for Livonia, largely due to the disappearance of native Prussians as a distinct ethnic group and a discontinuity in the use of pre-Christian sites in the post-medieval period. There have also been very few excavations of native settlements or cemeteries from the post-crusade period, although the few examples of the latter in eastern Prussia (e.g. Równina Dolna, Alt Wehlau, Stangenwalde, Gierdauen, Kreki and Bezławki; Koperkiewicz 2011) indicate that horse deposits were discontinued, whilst elites continued to be buried with rich grave good assemblages, including equestrian equipment, into the fifteenth century (Shiroukhov 2012). In contrast to Livonia, the creation of a Christian landscape is more clearly represented in Prussia.

Place fig $8 \mathrm{a}$ and $8 \mathrm{~b}$ near here, same page, vertically

After the crusading period, the population of Pomesania grew with both the foundation of new settlements by Christian migrants and continuing native communities, even resettlement from other regions of Prussia. A consistent number of native Prussian settlements existed in Pomesania from the thirteenth through to the later fourteenth century. In the fifteenth century, the documented number drops significantly: from seventy to fourteen. The corresponding number of designated native economic districts (Prussian lauks, German Feld) decreases during the fourteenth century as a result of cultural assimilation (and perhaps the impact of the Black Death which affected the Lower Vistula down to Thorn, as well as the Prussian littoral, in 1349-50; Benedictow 2004, 209), although free Prussians continue to be documented into the sixteenth century. Native sacred topography is represented by toponyms and references to stone monuments (so-called 'baby') which are regularly located on the boundaries of native territories (Szczepański 2010; 2015). Most of the ten Pomesanian territories have several identifiable cult sites or monuments (Figure 8) apparently shared by multiple neighbouring communities (Kawiński 2011). Since they are all listed in later sources where they feature as reference points for estate boundaries, they may represent a fossilised pre-crusade landscape, but also one that continued to hold meaning for native communities. The later desacralisation of sites is hinted at in a grant to one Peter Kater to fish in Lake Perkun, which straddled the border of three Pomesanian territories: Prosile, Geria and Rudenītai (Szczepański 2011, 155). Few native cemeteries are known from this region; one in the vicinity of the village of Jerzwałd and another near the village of Dobrzyki (in Geria). The cemetery associated with the village of Kreki (in the territory of the Pomesanian land Pobuz) is a rare example of a transitional burial ground dating to the twelfth and thirteenth century, featuring earlier cremation graves (particularly the distinctive Prussian Aschenplätze) and inhumations from the post-crusade period. The cemetery most likely served several neighbouring Prussian communities at a time when a Christian landscape was emerging around them. Whilst there is no evidence for continued cremation beyond the thirteenth century in this region (unlike in parts of eastern Prussia), there was continuity in ancestral memory and perhaps the reinforcement of earlier social structures at such sites. However, the absence of later graves at Kreki suggests the relocation of the burial ground, perhaps to the newly established parish church located five kilometres away at Arnsdorf (Polish Jarnołtowo), which appears in written sources in the first decade of the fourteenth century (Szczepański 2018).

A Christian topography was already being developed in Pomesania before the crusades, a reflection of Cistercian missionary activity across the frontier. As mentioned above, the Treaty of 
Christburg specified the rebuilding of destroyed churches and at least three churches may have been built on, or close to, pre-Christian cult sites (Szczepański 2011, 154). The sacral naming of key strongholds built by the Order in this region - Marienwerder, Christburg, Marienburg - provided more robust markers for the new sacred landscape. A new wave of church building commenced in the last two decades of the thirteenth century, with 47 parishes named by c. 1300. In the fourteenth century, the Order was particularly active in setting up parishes for migrants, and the diocese of Pomesania came to have the second highest number of parishes in Prussia after Ermland (Warmia): an overall total of 246 rural and 21 urban parishes, each serving an average of 2.5 settlements, in many cases just one. Six chapels are also mentioned in the thirteenth century, and the number increases by 48 in the fourteenth century (Wiśniewski 2016, 64). However, this parish network was less dense in areas occupied by Prussian communities, which in c1400 made up over half the population of the Pomesanian diocese but were served by only 27 parishes, all but three of them being shared with German subjects (Biskup 2013, 137-138). The provision of pastoral support was thus significantly skewed to the migrant population after the crusades. A comparable situation was found in the Sambian diocese, subdivided into only 49 parishes (of which five were urban) mapped onto the Order's smallest administrative districts (Kammerämter). This structure, the limited number of churches and the reliance on translators to engage with native congregants have been linked to the persistence of pre-Christian practices in this region (Biskup 2013, 136). It is therefore not surprising that descriptions of Prussian customs in the early decades of the sixteenth century suggest the existence of the same form of syncretism as in Livonia (Możdżeń 2011, 2013).

\section{Conclusion: Theocrats, Natives and Migrants}

This paper set out to assess how far the impact of regime change following the crusades was similar in Livonia and Prussia and it has demonstrated that the development of post-crusade sacred landscapes followed different trajectories in southern Estonia and Pomesania. In the former, Christian sacred topography became more developed within the episcopate of Dorpat, in contrast to Pomesania where it was more developed on the Order's lands. This can be linked to the Order's agenda relating to migrant settlements, and in both regions the Order's encouragement of church and chapel construction by native communities was comparatively limited. It is important to note that the Order and episcopates facilitated the construction of religious buildings through designations of land and access to building materials, rather than through finance (Radzmiński 2009, 159). The physical implementation of a new sacred landscape therefore reflects the agency of native and migrant communities. The abundant dataset for natural sacred sites in Estonia contrasts with the limited examples in Pomesania, but this difference is not solely a reflection of the relative survival of data; medieval sources are limited in both regions. The continuation of sacred sites in Estonia into the post-medieval period associated with the growth of native settlements contrasts with Pomesania, where the representation of the native population decreases by the sixteenth century. This reflects the ethnic mosaic of medieval settlement in Pomesania and the long-term impact of Germanisation (and to a lesser degree Polonisation, as Polish-speaking communities were also present). Crucially, this meant that new religious sites designated from the fourteenth cetury were associated with Christianity, rather than with native spirituality. The largely ethnic separation between urban and rural communities in Livonia and parts of Prussia resulted in the persistence of non-Christian practices in the countryside. Many have argued that native peasants were completely detached from 
the Christian worldview even into the seventeenth century, and that pagan or syncretised paganChristian practices may even have been revived (or reinvented) during the turmoil of the Reformation (Urtāns 2008a, 15-17, 31, 96). Whilst there were synodial condemnations of lingering native customs in the fifteenth century, cult sites could be re-designated, making the suppression of this practice virtually impossible as evident in Latvia in the early eighteenth century (Urtāns 2008a, 106).

The territorial role of native sacred sites declined following the post-crusade imposition of theocratic administrative districts and the accompanying demographic changes. In terms of relative diocesan size, the Estonian part of Livonia was significantly larger than Pomesania or Sambia, but the high number of parishes in Pomesania and their relative paucity in Sambia and Estonia, despite the growing populations, is an important indicator of the variable dissemination of Christianity. Investment in religious infrastructure varied between the Teutonic Order and the episcopates, and the political tensions between them were such that at times they erupted into dramatic examples of violence and church defilement, particularly by the Order which violated the privileges of churches, including the right to asylum (Simiński 2013). The emphasis on active conversion had traditionally come from the papacy, but intensive lobbying by the Order and the Livonian episcopate in the curia, particularly in the fifteenth century, could privilege political ends (Eihmane 2012). The Order's role was promoted and perceived as engaging in holy war for the defence of Christendom, rather than as missionary activity. More pronounced evangelising efforts are associated with the episcopates, but beyond the overarching framework of the diocesan system, the ongoing creation of sacred landscapes in the post-crusade period was idiosyncratic and visibly linked to the diachronic distribution and growth of native and migrant populations.

The tempo of change is arguably most visible in cemeteries. Most data comes from southern Estonia, and the pace at which native Prussians in Pomesania abandoned their ancestral cemeteries in favour of parochial ones is unclear because native burial grounds of this period have been difficult to locate in Pomesania where a historical lack of interest in excavating medieval cemeteries is also evident. But the process evidently continued up to the sixteenth century. Not all native Prussian cemeteries were abandoned during the period of theocratic rule; e.g. Równina Dolna was used into the fifteenth century and Alt Wehlau into the seventeenth century. Where ecclesiastical authorities were most visible and influential in Livonian towns, and presumably in Prussia where natives joined urban communities, burial rites became standardised and indistinguishable from those of Christian migrants and their descendants (Valk 2004a). Protestants in Pomesania built additional religious structures, including cemeteries (Wiśniewski 2016). This would have increased the level of Christian pastoral support for communities which still identified as native and accelerated the process of religious homogenisation. For any lingering traces of native spirituality, hybridised or otherwise, the coup de grâce would have been the impact of the Counter Reformation, which increased in ferocity by the late sixteenth century and saw a battle for 'hearts and minds' between Protestants and Catholics in 'Royal Prussia', the territories which had been ceded by the Teutonic Order in 1466. In Livonia, however, the mass destruction of local offering sites only began in the mid-nineteenth century, as part of the broader abandonment of earlier traditions (Loorits 1935, 295-296). Ultimately, the impact of the crusades on the sacred landscapes of the eastern Baltic can only be understood by adopting an inter-regional, long-term perspective. Moreover this comparative study of 
the nature of religious transformation in Prussia and Estonia highlights the importance of avoiding generalisations for superficially similar regions, particularly where datasets are limited.

\section{Acknowledgements}

The research leading to these results received funding from the European Union's Seventh Framework Programme (FP7/2007-2013, grant agreement $n^{\circ} 263735$ ) and the Estonian Ministry of Education and Science (institutional research theme IUT 20-7). We would like to thank Prof.

Grenville Astill for his comments.

\section{Abbreviations}

GQK Geschichte der Quellen des katholischen Kirchenrechts der Provinzen Preussen und Posen (Jacobson 1837)

LUB Liv-, Est- und Kurländisches Urkundenbuch nebst regesten (Bunge 1853-1857)

PUB 1/1 Preussisches Urkundenbuch (Philippi 1882).

PUB 3/1 Preussisches Urkundenbuch (Hein 1944).

\section{References}

\section{Primary sources}

Bunge, F. G., von, ed. 1853-57. Liv-, Est- und Kurländisches Urkundenbuch nebst regesten, (vols IIII), Reval: Kluge and Ströhm (13 volumes, most recent 2018)

Hein, M. ed. 1944. Preußisches Urkundenbuch (1335-1341). Volume 3/1. Königsberg (http://www.spaetmittelalter.uni-hamburg.de/Urkundenbuch/).

Jacobson H. F. ed 1837. Geschichte der Quellen des katholischen Kirchenrechts der Provinzen Preussen und Posen. Volume 1. Königsberg.

Philippi, R. ed. 1882. Preußisches Urkundenbuch. Politische Abteilung. Volume 1/1. Königsberg.

\section{Secondary sources}

Benedictow, O. 2004. The Black Death, 1346-1353: The Complete History, Boydell.

Benninghoven, F. 1963. Probleme der Zahl und Standortverteilung der livländischen Streitkräfte im ausgehenden Mittelalter. Zeitschrift für Ostforschung 12, 601-622.

Bertašius, M. 2005. Marvele, Ein Gräberfeld Mittellitauens, Kauno Technologijos Universitetas. 
Bertašius, M. 2006. From social expression to institutionalized religion. Making an attempt of central Lithuania. In Transformatio Mundi: The Transition from the Late Migration Period to the Early Viking Age in the East Baltic, ed. M. Bertašius, Kaunas University of Technology, 65-71.

Bertašius, M. 2012. Horse burials as public ritual: Lithuanian perspectives. In The Ritual Killing and Burial of Animals in the Past: European Perspectives, ed. A. G. Pluskowski, Oxbow, 61-75.

Biskup, M. 2013. Parafie w państwie krzyżackim. In Zakon krzyżacki w Prusach i Inflantach: podziały administracyjne i kościelne w XIII-XVI wieku, eds. R. Czaja and A. Radzimiński, Wydawnictwo Naukowe Uniwersytetu Mikołaja Kopernika, 129-149.

Biskup, M. Czaja, R. Długokęcki, W. Dygo, M. Jóźwiak, S. Radzimiński, A. and Tandecki, J. eds. 2009. Państwo zakonu krzyżackiego w Prusach. Władza i społeczeństwo, Wydawnictwo Naukowe PWN.

Biskup, R. and Radzimiński, A. eds. 2015. Parafie w średniowiecznych Prusach w czasach zakonu niemieckiego od XIII do XVI w. Wydawnictwo Naukowe Uniwersytetu Mikołaja Kopernika.

Bonow, M. Cios, S. and Svanberg, I. 2016. Fishponds in the Baltic states: Historical cyprinid culture in Estonia, Latvia and Lithuania. In Historical Aquaculture in Northern Europe, eds. M. Bonow, O. Håkan and I. Svanberg, Södertörns högskola, 139-156.

Brown, A. 2018a. Vegetation changes in Livonia: The palynological data. In Environment, Colonisation, and the Crusader States in Medieval Livonia and Prussia, ed. A. G. Pluskowski, Brepols, in press.

Brown, A. 2018b. Vegetation changes in Prussia: The palynological data. In Environment, Colonisation, and the Crusader States in Medieval Livonia and Prussia, ed. A. G. Pluskowski, Brepols, in press.

Brūzis, R. and Spirğis, R. 2011. The Ogresgala Čabas cemetery and horse sacrifice. Archaeologia Baltica 11, 283-294.

Caune, A. 1992. Arheologískās liecības par senāko apdzīvotību Rīgas Doma baznīcas apkārtnē. Latvijas Vēstures Institūta Žurnāls 3, 21-38.

Christiansen, E. 1997. The Northern Crusades, Penguin (second edition).

Czaja, R. and Radzimiński, A. eds. 2013. Zakon krzyżacki w Prusach i Inflantach: podziały administracyjne i kościelne w XIII-XVI wieku, Wydawnictwo Naukowe Uniwersytetu Mikołaja Kopernika. 
Jahnke, C. 2015. The Baltic trade. In A Companion to the Hanseatic League, ed. D. J. Harreld, Brill, 194-240.

Frascaroli, F. and Verschuuren, B. 2016. Linking biocultural diversity and sacred sites: Evidence and recommendations in the European framework. In Biocultural Diversity in Europe, eds. M. Agnoletti and F. Emanueli, Springer, 389-417.

Fonnesberg-Schmid, I. 2007. The Popes and the Baltic Crusades: 1147-1254, Brill.

Gąssowska, M. 2006. Livländer auf der Wallfahrt nach Wilsnack und das Heilige Blut zu Riga. In Die Willsnackfahrt. Ein Wallfahrts- und Kommunikationszentrum Nord- und Mitteleuropas im Spätmittelalter, ed. F. Escher, Peter Lang, 97-113.

Heinapuu, O. 2016. Agrarian rituals giving way to Romantic motifs: Sacred natural sites in Estonia. Sign Systems Studies 44/1-2, 164-185.

Jonuks, T. 2007. Holy groves in Estonian religion. Estonian Journal of Archaeology 11 (1), 3-35.

Jonuks, T. ed. 2009. Sacred Natural Places. Folklore 42 (special issue).

https://www.folklore.ee/folklore/vol42/

Jonuks, T. 2012a. Hiis-sites in the parishes of Rapla and Juuru. In Estonian Journal of Archaeology. Supplementary Series, 1, 168-183.

Jonuks, T. 2012b. From holy hiis to sacred stone: diversity and dynamic meanings of Estonian holy sites. In Rountree, K., et al. (eds). Archaeology of Spiritualities. Springer, 163-183.

Karczewski, M. 2008. Zmiany poziomu lustra wody w jeziorach mazurskich w ciągu ostatnich dwóch tysięcy lat w świetle źródeł archeologicznych i historycznych. In Polska północno-wschodnia w holocenie. Człowiek i jego środowisko. eds. A. Wacnik, and E. Madeyska, Instytut Botaniki im. W. Szafera PAN, 47-75.

Kawiński, P. 2011. Organizacja pogańskiej przestrzeni sakralnej Prusów na tle osadnictw a w okresie plemiennym - przykład Pomezanii, Pogezanii i Warmii. Pruthenia 6, 89-128.

Kawiński, P. 2018. Sacrum $w$ wyobrażeniach pogańskich Prusów. Próba interpretacji na pograniczu historii i etnologii religii. Towarzystwo Naukowe Pruthenia.

Kawiński, P. and Szczepański, S. 2016. Szkice o religii Prusów, Towarzystwo Naukowe Pruthenia. 
Kḷaviņš, K. 2011. Sacred forests and trees in Latvia and in the Latvian mind. In Environmental Philosophy and Landscape Thinking, eds. L. Lukas, U. Plath and K. Tüür, Underi ja Tuglase Kirjanduskeskus, 259-267.

Kutzner, M. 1995. Propaganda władzy w sztuce Zakonu Niemieckiego w Prusach. In Sztuka w kręgu zakonu krzyżackiego w Prusach i Inflantach, ed. M. Woźniak, Uniwersytet Mikołaja Kopernika, 3285.

Kõivupuu, M. 2009. Natural sacred places in landscape: an Estonian model. In Nature, Space and the Sacred: Transdisciplinary Perspectives, ed. S. Bergmann, Ashgate, 223-233.

Koperkiewicz, A. 2011. Bezławki - cmentarzysko. Przyczynek do badań and chrystianizacją ziem pruskich. Pruthenia 6, 281-301.

Kregždys, R. 2012. Baltu mitologemu etimologijas žodynas, t. I: Kristburgo sutartis, Lietuvos kultūros tyrimų institutas.

Laime, S. 2009. The sacred groves of the Curonian Ķonini: Past and present. Folklore 42, 67-80.

Lang, V. 2017. Riding to the afterworld: Burying with horses and riding equipment in Estonia and the Baltic rim. In Identity Formation and Diversity in the Early Medieval Baltic and Beyond, eds. J. Callmer, I. Gustin and M. Roslund, Brill, 48-75.

Lazda-Cazers, R. 2009. Landscape as other in the Livländische Reimchronik. Amsterdamer Beiträge zur älteren Germanistik 65, 183-209.

Loorits O. 1935. Mulgimaa ohvrikohad. Kaleviste mailt. Õpetatud Eesti Seltsi Kirjad 3, 225-300.

Markus, K. 1999. Från Gotland till Estland. Kyrkokonst och politik under 1200-taler. Mercur Consulting OY.

Możdżeń, J. 2011. Synkretyzm religijny Prusów na podstawie kroniki Szymona Grunaua. Pruthenia 6, 221-248.

Możdżeń, J. 2013. 'Von ihrem irtumb und seltzam wan noch heutt in tagk'. The role of real life experience in the records of the Prussians made by Szymon Grunau (Mid-15th century-1529/30). In Conversions. Looking for Ideological Change in the Early Middle Ages, eds. L. Słupecki and R. Simek, Fassbaender, 223-264.

Muižnieks, V. 2015. Bēru tradīcijas Latvijā pēc arheologiski pètīto 14.-18. gadsimta apbedīšanas vietu materiāla. (Latvijas Nacionāla Vēstures Muzeja Raksti 21). Latvijas Nacionāla Vēstures Muzejs. 
Murray, A.V. 2016. Catholic missionaries in the evangelization of Livonia, 1185-1227. In Quis est qui ligno pugnat? Missionari ed evangelizazzione nell'Europa tardoantica e medievale (secc. IVXIII), ed. E. Piazza, Alteritas - Interazione tra i popoli, 353-366.

Nielsen, T. K. 2011. Henry of Livonia on woods and wilderness. In Crusading and Chronicle Writing on the Medieval Baltic Frontier: A Companion to the Chronicle of Henry of Livonia, ed. M. Tamm, Ashgate, 157-178.

Nielsen, T. K. 2013. The making of new cultural landscapes in the medieval Baltic. In Medieval Christianity in the North: New Studies, ed. K. Salonen, Brepols, 121-153.

Paravicini, W. 1989. Die Preußenreisen des europäischen Adels (2 volumes), Thorbecke.

Pluskowski, A. G. ed. 2018. Environment, Colonisation, and the Crusader States in Medieval Livonia and Prussia: Terra Sacra I, Brepols.

Pluskowski, A. G. Kḷaviņš, K. Eihmane, E. Dzenis, A. and Kreem, J. 2018. Reorganising the Livonian Landscape. In Environment, Colonisation, and the Crusader States in Medieval Livonia and Prussia: Terra Sacra I, ed. A. G. Pluskowski, Brepols, in press.

Poliński, D. 2003. Późnośredniowieczne osadnictwo wiejskie w ziemi chetmińskiej, Wydawnictwo Naukowe Uniwersytetu Mikołaja Kopernika.

Radzmiński, A. 2009. Geneza oraz ukształtowanie się organizacji kościelnej (1206-1409). In Państwo zakonu krzyżackiego w Prusach. Władza i społeczeństwo, eds. M. Biskup, et al., Wydawnictwo Naukowe PWN, 142-176.

Radzimiński, A. 2015. Uwagi na temat pogaństwa Prusów w późniejszym średniowieczu. In Memoria viva. Studia historyczne pamięci Izabeli Skierskiej, eds. G. Rutkowska, A. Gąsiorowski, IH PAN, 436-444.

Rammo, R. and Veldi, M. 2005. Archaeological excavations at Musumägi Hill in Viljandi. Arheoloogilised välitööd Eestis / Archaeological Fieldwork in Estonia 2004, 103-116.

Rozynkowski, W. 2006. Omnes Sancti et Sanctae Dei: Studium nad kultem świętych w diecezjach pruskich państwa zakonu krzyżackiego, Wydawnictwo Muzeum Zamkowe w Malborku.

Simiński, R. 2013. Church as sacred space in the light of thirteenth and fifteenth century Livonian and Prussian sources. In Sacred Space in the State of the Teutonic Order in Prussia, ed. J. Wenta, Wydawnictwo Naukowe Uniwersytetu Mikołaja Kopernika, 291-307. 
Shiroukhov R. 2012. Prussian graves in the Sambian peninsula with imports, arms and horse harnesses from the tenth to the 13th century: the question of warrior elite. Archaeologia Baltica, 18: 224-255.

Spekke, A. 1995. Latvieši un Livonija 16. g.s. A. Gulbis.

Steege, H. 1993. Das Mühlewesen im Deutschordensland. Westpreußen-Jahrbuch 43, 94-106.

Švābe A. 1938. Kuř̌̌ ķoningi un novadnieki. Straumes un avoti.

Szczepański, S. 2010. Czy pruskie miejsca święte? Nazwy miejscowe i fizjograficzne z obszaru historycznej Pomezanii i obszarów sąsiednich w dokumentach krzyżackich. Pruthenia 5, 133-160.

Szczepański, S. 2011. Sakralizacja obszaru pogranicza na przykładzie Pomezanii pruskiej. Pruthenia $6,129-156$.

Szczepański, S. 2013. Chomor Sancti Adalberti (1249): a możliwości lokalizacji terenowej wybranych kościołów Pomezanii. Komunikaty Mazursko-Warmińskie 1 (279), 19-45.

Szczepański, S. 2015. Old Prussian 'Baba' Stones: An overview of the history of research and reception. Pomesanian-Sasinian Case. Analecta Archaeologica Ressoviensia 10, 313-364.

Szczepański, S. 2016. Pomezania Pruska: Dzieje osadnictwa w XIII-XV wieku, Ośrodek Badań Naukowych im. Wojciecha Kętrzyńskiego.

Szczepański, S. 2017. Traktat dzierzgoński (1249) a elementy religijności Prusów. Tabularium Historiae 2, 75-98.

Szczepański, S. 2018. Surkapurn - Kreken: The phenomenon of a name - the phenomenon of a place. The organisation of sacred space in Prussia using archaeology and other sources. In Ecologies of Crusading, Colonisation and Religious Conversion in the Medieval Eastern Baltic. Terra Sacra II, ed. A. G. Pluskowski, Brepols.

Thomas, G., Pluskowski, A. G., Gilchrist, R., García-Contreras Ruiz, G., Andrén, A., Augenti, A., Astill, G. , Staecker, J. and Valk, H. 2017. Religious transformations in the Middle Ages: Towards a new archaeological agenda. Medieval Archaeology 61(2), 300-329.

Urban, W. 2003. The Teutonic Knights: A Military History, Greenhill Books.

Urtāns, J. 2008a. Ancient Cult Sites of Semigallia, Nordik.

Urtāns, J. 2008b. Augšzems Ezeri, Nordik. 
Urtāns, J. 2009. Semigallian church sites in folklore and the archaeological evidence. In The Reception of Medieval Europe in the Baltic Sea Region, ed. J. Staecker, Gotland University Press, 263-271.

Urtāns, J. 2011 (ed.) Kultūras krustpunkti, 5. Dabas svēvietas vai svētvietas dabā: identifificēšana, atklāšana un klasificēšana. Turaida, 2009. gada maijs. Starptautiskas zinātniskās konferences materiāli. Nordik.

Vaitkevičius, V. 2004. Studies into the Balts'Sacred Places, Archaeopress.

Vaitkevičius, V. 2009. The sacred groves of the Balts: Lost history and modern research. Folklore 42, 81-94.

Vaitkevičius, V. 2011. Ancient sacred places in Lithuania: Crossroads of geography, archaeology and folklore. Archaelogia Baltica 15, 45-55.

Vaitkevičius, V. 2018. Continuity and discontinuity in the sacral landscape of Lithuania. In The Ecologies of Crusading, Colonisation and Religious Conversion in the Medieval Eastern Baltic. Terra Sacra II, ed. A. G. Pluskowski, Brepols (in press).

Vaitkevičius, V. and Vaitkevičienè, D. eds. 2011. Archaeology, religion, and folklore in the Baltic Sea Region. Archaeologia Baltica 15 (special issue).

Valk, H. 2001. Rural Cemeteries of Southern Estonia: 1225-1800 AD, Archaeology Centre, University of Tartu.

Valk, H. 2003. Christianisation in Estonia: a process of dual-faith and syncretism. In The Cross Goes North. Processes of Conversion in Northern Europe, AD 300-1300, ed. M. Carver, Boydell, 571579.

Valk, H. 2004a. Artefacts in Estonian urban Churchyards: Reflections on different Traditions and Ideologies. In Der Ostseeraum und Kontinentaleuropa 1100-1600, eds. D. Kattinger, J. E. Olesen, and H. Wernicke, T. Helms, 103-112.

Valk, H. 2004b. Christian and non-Christian holy sites in medieval Estonia: A reflection of ecclesiastical attitudes towards popular religion. In The European Frontier. Clashes and Compromises in the Middle Ages. International Symposium of the Culture Clash or Compromise (CCC) project and the Department of Archaeology, Lund University, held in Lund October 13-15 2000. (CCC Papers, 7. Lund Studies in Medieval Archaeology, 33). Lund, 299-310.

Valk, H. 2009. Sacred and natural places of Estonia: regional aspects. Folklore 42, 45-66. 
Valk, H. 2017. On the Origins of Churches and Churchyards in Southern Estonia: the Evidence from Early Grave Finds. In Baltic Journal of Art History, 13, 99-129.

Valk, H. 2018. Sacred landscapes of medieval Livonia: lands of the Teutonic Order in southern Estonia. In Ecologies of Crusading, Colonisation and Religious Conversion in the Medieval Eastern Baltic. Terra Sacra II, ed. A. G. Pluskowski, Brepols (in press).

Wenta, J. 2011. Holy islands and their Christianization in medieval Prussia. In Islands and Cities in Medieval Myth, Literature, and History, ed. A. Grafetstätter, Peter Lang, 37-54.

Wenta, J. ed. 2013. Sacred Space in the State of the Teutonic Order in Prussia, Wydawnictwo Naukowe Uniwersytetu Mikołaja Kopernika.

Williams, H. 2004. Death warmed up: The agency of bodies and bones in early Anglo-Saxon cremation rites. Journal of Material Culture 9 (3), 263-291.

Williams, H. 2005. Re-thinking early medieval mortuary archaeology. Early Medieval Europe 13 (2), 195-217.

Wiśniewski, J. 2016. Pomezańskie parafie de iure jako filie diecezji Elbląskiej de facto, Studia Elblaskie 17, 33-70.

\section{Notes on Contributors}

Aleksander Pluskowski is Associate Professor of Medieval Archaeology at the Department of Archaeology at the University of Reading, UK. His research focuses on the relationship between nature and culture in medieval Europe, particularly within frontier societies associated with crusading, colonisation, cultural encounters and religious transformations.

a.g.pluskowski@ reading.ac.uk

Heiki Valk is senior research fellow at the Institute of History and Archaeology at the University of Tartu, Estonia. His research concerns the connections between medieval rural archaeology and folklore, ethnology and popular religion, regarding the native culture of medieval Livonia and also within a broader European context. heiki.valk@ut.ee

Seweryn Szczepański is Adjunct Professor at the Wojciech Kętrzyński Research Centre in Olsztyn, Poland. His research focuses on the history and culture of medieval Prussia, particularly the settlement, mythology and Christianisation process of the Old Prussians. He is also interested in the history of the archaeology of East Prussia during the Nazi era. seweryn.szczepanski@op.pl 


\section{Figure captions}

Figure 1. Map showing the eastern Baltic with the territorial boundaries of Prussia from c. 1400 (aft. Biskup et al. eds. 2009, with the Kulmerland after Poliński 2003, map 2) and Livonia c. 1450 (after Benninghoven 1963), and the outline of the Danish Duchy of Estonia created during the crusading period and sold to the Teutonic Order in 1346. The territories of the Order and bishops discussed as case studies are marked. (Maps: Pluskowski)

Figure 2. The Teutonic Order's canal at Jurkowice, Sztum county, Pomeranian voivodeship. (Photo: Magnus Elander)

Figure 3. The eastern end of the church in the upper castle at Malbork (German Marienburg), the headquarters of the Teutonic Order from 1309-1457, in the Pomeranian voivodeship, Poland, with the recently restored statue of the crowned Virgin and Child. Constructed in the 1340s and over eight metres tall, this sculpture was the largest and most potent symbol of the divine mandate for the Order's rule in the Baltic. (Photo: Pluskowski)

Figure 4. The 'offering stone' on the shore of Lake Mój, Kętrzyn district, Warmian-Masurian voivodeship, Poland. (Photo: Pluskowski)

Figure 5. A boulder carved with a cross near Āraiši, Drabeši parish, Amata municipality, Latvia. (photo: O.Erdmanis, 1928. National History Museum of Latvia, Ref. 12499)

Figure 6. Sacred natural sites in southern Estonia, within the historical territories of the Teutonic Order and the Episcopate of Dorpat according to folkloric and toponymic evidence. (Map: Valk)

Figure 7. Chapel sites within the historical territories of the Teutonic Order and the Episcopate of Dorpat according to folkloric and toponymic evidence. (Map: Valk)

Figure. 8. Maps showing a) Native Prussian territories in Pomesania where b) sacred sites have been identified alongside pre-crusade strongholds and native settlements from the thirteenth to fifteenth centuries. (Maps: Szczepański)

\footnotetext{
${ }^{1}$ The term 'pagan' is used in this article for the sake of convenience to refer to native religions in the eastern Baltic, whilst acknowledging that its contemporary use in Christian sources (alongside 'heathen') is both a derogatory and generic label for religious otherness. For the latest work on Balt pagan beliefs see Kregždys 2012, Radzimiński 2015 and Kawiński 2018.
} 